\title{
PENGARUH PROFITABILITAS, LIKUIDITAS, LEVERAGE KEUANGAN, DAN UKURAN PERUSAHAAN TERHADAP KETEPATAN WAKTU PELAPORAN KEUANGAN PERUSAHAAN KONTRAKTOR
}

\section{Beny Fatahillah AB, Fitriana dan Didin Saepudin}

Program Studi Akuntansi, Universitas Sangga Buana YPKP Bandung

Email: benyfatahillah@gmail.com, fitrianadachlan64@gmail.com dan didin.saepudin@usbypkp.ac.id

\begin{abstract}
Abstrak
Bursa Efek Indonesia (BEI) menyatakan ada 70 perusahaan terbuka atau emiten yang belum menyampaikan laporan keuangan kuartal I-2017, Sebelumnya pada 21 Maret 2017, dinyatakan bahwa BEI telah menghentikan sementara perdagangan saham 27 perusahaan yang melantai di bursa. Langkah otoritas bursa menghentikan perdagangan saham emiten tersebut karena beberapa penyebab, Bursa Efek Indonesia (BEI) menghentikan sementara (suspensi) perdagangan 10 saham. Belum menyampaikan laporan keuangan auditan ke regulator bursa. Tujuan dari penelitian ini adalah untuk mengetahui (1) pengaruh profitabilitas terhadap ketepatan waktu pelaporan keuangan perusahaan kontraktor yang terdaftar di Bursa Efek Indonesia, (2) pengaruh likuiditas terhadap ketepatan waktu pelaporan keuangan perusahaan kontraktor yang terdaftar di Bursa Efek Indonesia, (3) pengaruh leverage keuangan terhadap ketepatan waktu pelaporan keuangan perusahaan kontraktor yang terdaftar di Bursa Efek Indonesia, (4) pengaruh ukuran perusahaam terhadap ketepatan waktu pelaporan keuangan perusahaan kontraktor yang terdaftar di Bursa Efek Indonesia, sampel yang diperoleh dari penelitian ini adalah 33 perusahaan. Data yang digunakan laporan keuangan tahunan perusahaan yang telah diaudit dan terdaftar di Bursa Efek Indonesia. Metode penelitian ini menggunakan metode deskriptif analisis verifikatif dengan Analisis Regresi Logistik Probit. Hasil penelitian menunjukan bahwa ; (1) profitabilitas diperoleh nilai sig dari variable ROE sebesar 0.460. Nilai sig. ROE tersebut >0.05, sehingga variable ROE tidak dapat berpengaruh secara parsial terhadap variable Ketepatan Waktu, (2) likuiditas diperoleh nilai sig dari variable Cash Ratio sebesar 0.719. Nilai sig. Cash Ratio tersebut $>0.05$ sehingga variable Cash Ratio tidak dapat berpengaruh secara parsial terhadap variable Ketepatan Waktu, (3) leverage keuangan diperoleh nilai sig dari variable DAR sebesar 0.899. Nilai sig. DAR tersebut > 0.05 sehingga variable DAR tidak dapat berpengaruh secara parsial terhadap variable Ketepatan Waktu, (4) ukuran perusahaan diperoleh nilai sig dari variable Ukuran Perusahaan sebesar 0.346. Nilai sig. Ukuran Perusahaan tersebut $>0.05$ sehingga variable Ukuran Perusahaan tidak dapat berpengaruh secara parsial terhadap variable Ketepatan Waktu.
\end{abstract}

Kata kunci : Profitabilitas, Likuiditas, Leverage keuangan, dan Ukuran Perusahaan 


\section{Pendahuluan}

Perkembangan dunia usaha saat ini dan tentunya di masa mendatang bisnis perusahaan pun akan semakin kompleks dengan tingkat persaingan yang semakin ketat, maka diperlukan adanya upaya dalam penyediaan dan kemudahan informasi. Ketepatan waktu (timeliness) penyampaian laporan keuangan sebagai salah satu yang harus diperhatikan oleh perusahaan karena sangat dibutuhkan oleh pemakai laporan untuk pengambilan keputusan menjadi relevan dan tepat, dan serta akan memberikan manfaat kepada perusahaan dalam hal perluasan usaha dan belanja modal.

Di Indonesia, setiap perusahaan diharuskan untuk menyampaikan laporan keuangan yang disusun sesuai dengan Standar Akuntansi Keuangan dan telah diaudit oleh akuntan publik. Perusahaan yang terlambat menyampaikan laporan keuangan kepada Bursa Efek Indonesia (BEI) akan diberikan peringatan tertulis dan sanksi administrasi sesuai dengan ketentuan pasal 63 huruf E peraturan pemerintah Nomor 45 tahun 1995 tentang penyelenggaraan kegiatan di Bidang Pasar Modal (Astuti \& Erawati, 2018). Perusahaan yang dikategorikan tidak tepat waktu (terlambat) dalam penyampaian laporan keuangan apabila melaporkan setelah tanggal 31 Maret (Valentina, 2018). Ketepatan waktu pelaporan keuangan serta aturan-aturan yang mewajibkannya, namun dalam kenyataannya masih banyak perusahaan yang terlambat melaporkan laporan keuangan setiap tahunnya. Perusahaan yang go public diwajibkan untuk menyampaikan laporan keuangan yang disusun sesuai dengan Standar Akuntansi Keuangan dan telah diaudit oleh akuntan publik yang terdaftar di Otoritas Jasa Keuangan (OJK). Peraturan mengenai penyampaian laporan keuangan tersebut diatur oleh OJK dalam Nomor 29 / POJK.04/2016, Pasal 7 berbunyi ; Emiten atau Perusahaan Publik wajib menyampaikan Laporan Tahunan kepada Otoritas Jasa Keuangan paling lambat pada akhir bulan keempat setelah tahun buku berakhir. Berdasarkan Kerangka Dasar Penyusunan dan Penyajian Laporan Keuangan Standar Akuntansi Keuangan (Indonesia, 2017) laporan keuangan yang baik harus memenuhi empat karakteristik kualitatif yang merupakan ciri khas informasi laporan keuangan yang berguna bagi para pemakainya. Keempat karakteristik tersebut yaitu dapat dipahami, relevan, andal, dan dapat diperbandingkan. Untuk mendapatkan informasi yang relevan tersebut, terdapat beberapa kendala, salah satunya adalah kendala ketepatan waktu. Hal ini sesuai dengan PSAK No.1 Tentang Penyajian Laporan Keuangan paragraf 43, yaitu jika terdapat penundaan yang tidak semestinya dalam pelaporan, maka informasi yang dihasilkan akan kehilangan relevansinya. Laporan keuangan harus dibuat berdasarkan Standar Akuntansi Keuangan (SAK), dan terdiri dari neraca, laporan laba rugi dan laporan arus kas, pengungkapan mengenai kebijakan akuntansi dan catatan yang menyertai laporan keuangan (Riswan \& Saputri, 2016). Dengan adanya suatu entitas yang disajikan maka dapat digunakan untuk pembuatan keputusan ekonomi (Siagian \& Indra, 2019). Bursa Efek Indonesia (BEI) menyatakan ada 70 perusahaan terbuka atau emiten yang belum menyampaikan laporan keuangan kuartal I-2017. Padahal seharusnya, emiten tersebut harus menyampaikan laporan keuangan paling lambat akhir April (Liputan.6.com \& CNBC Indonesia.com). 
Atas keterlambatan ini, Otoritas bursa memberikan peringatan kepada perusahaan-perusahaan tersebut. Jika emiten masih membandel, BEI tak segan-segan menghentikan sementara perdagangan saham (suspensi) dari emiten tersebut.

"Sebanyak 70 perusahaan belum menyampaikan laporan keuangan kuartal I2017," tegas Direktur Penilaian BEI, Samsul Hidayat usai menghadiri acara Peluncuran Strategi Perlindungan Konsumen Keuangan (SPKK) Otoritas Jasa Keuangan (OJK) di Gedung BEI, Jakarta, Kamis (18/5/2017). (Liputan.6.com \& CNBC Indonesia.com).

Sebelumnya pada 21 Maret 2017, dinyatakan bahwa BEI telah menghentikan sementara perdagangan saham 27 perusahaan yang melantai di bursa. Langkah otoritas bursa menghentikan perdagangan saham emiten tersebut karena beberapa penyebab.

Dari 27 perusahaan yang dibekukan tersebut, ada beberapa perusahaan yang terancam bakal dikeluarkan dari papan perusahaan terbuka (delisting). Alasannya, perusahaan ini tidak memenuhi keterbukaan seperti laporan keuangan dalam dua tahun.

Bursa Efek Indonesia (BEI) menghentikan sementara (suspensi) perdagangan 10 saham. Belum menyampaikan laporan keuangan auditan ke regulator bursa. Keterlambatan pelaporan (audit delay) akan menimbulkan reaksi negatif dari pelaku pasar modal karena laporan keuangan audit memuat informasi tentang laba yang dihasilkan perusahaan yang digunakan para pelaku pasar modal untuk memprediksi nilai perusahaan, dalam hal ini adalah harga sahamnya, dan informasi lainnya yang dapat dipergunakan untuk mengambil keputusan ekonomi.

Atas dasar itu penulis mencoba menelusuri lebih jauh terhadap beberapa perusahaan yang tercatat di BEI, dan ternyata masih terdapat beberapa perusahaan yang terlambat melaporkan laporan keuangan setiap tahunnya. Berdasarkan pengamatan yang dilakukan terhadap kurang lebih 77 perusahaan kontraktor, khusus yang bergerak di bidang Jasa Kontruksi Bangunan, Real Estate dan Property tahun 2013 - 2018, tahun 2013 terdapat sekitar $15 \%$ perusahaan publik telat menyajikan laporan keuangannya, tahun 2014 terdapat $56 \%$ perusahaan publik telat menyajikan laporan keuangannya, tahun 2015 terdapat $85 \%$ perusahaan publik telat menyajikan laporan keuangannya, tahun 2016 terdapat $29 \%$ perusahaan publik telat menyajikan laporan keuangannya, tahun 2017 terdapat $12 \%$ perusahaan publik telat menyampaikan laporan keuangannya dan pada tahun 2018 terdapat $8 \%$ perusahaan publik telat menyajikan laporan keuangannya.

\section{Metode Penelitian}

Metode yang digunakan dalam penelitian ini adalah dengan menggunakan analisis kuantitatif dengan menganalisis suatu permasalahan yang ada dengan cara mengkuantifikasikan data yang diperoleh dalam penelitian sehingga menghasilkan informasi yang dibutuhkan. Metode deskriptif ini merupakan metode yang bertujuan untuk mengetahui sifat serta hubungan yang lebih mendalam antara variabel dengan cara mengamati aspek-aspek tertentu secara lebih spesifik untuk memperoleh data yang sesuai dengan masalah yang ada dengan tujuan penelitian, dimana data tersebut diolah, 
dianalisis, dan diproses lebih lanjut dengan dasar teori-teori yang telah di pelajari sehingga data tersebut dapat ditarik sebuah kesimpulan (Sugiyono, 2017).

\section{Hasil dan Pembahasan}

\section{Hasil Penelitian}

a. Analisis Deskriptif

1) Ketepatan Waktu Penyampaian laporan keuangan pada Perusahaan Kontraktor (terdaftar di BEI)

Jumlah populasi dalam penelitian ini adalah 198 dimana terdapat 33 sampel perusahaan dan tahun yang diteliti selama 6 tahun dari tahun 2013 sampai dengan 2018. Dalam penelitian ini, ketepatan waktu merupakan variabel independen.Ketepatan waktu adalah informasi yang ada dan siap untuk digunakan sebelum kehilangan makna oleh pemakai laporan keuangan serta kapasitasnya masih tersedia dalam pengambilan keputusan. Ketepatan Waktu diukur dengan Tepat Waktu $(\leq 4$ bulan $)=1$ dan Tidak Tepat Waktu ( $>4$ bulan $)=0$

2) Profitabilitas Perusahaan Kontraktor Yang Terdaftar Di Bursa Efek Indonesia Tahun 2013-2018

Dalam penelitian ini profitabilitas merupakan variabel dependen. Return of Equity (ROE) merupakan rasio yang mengukur kemampuan perusahaan menghasilkan keuntungan (profitabilitas).

\section{Grafik 1}

Nilai Rata-Rata Profitabilitas (ROE) Perusahaan Kontraktor

Tahun 2013-2018

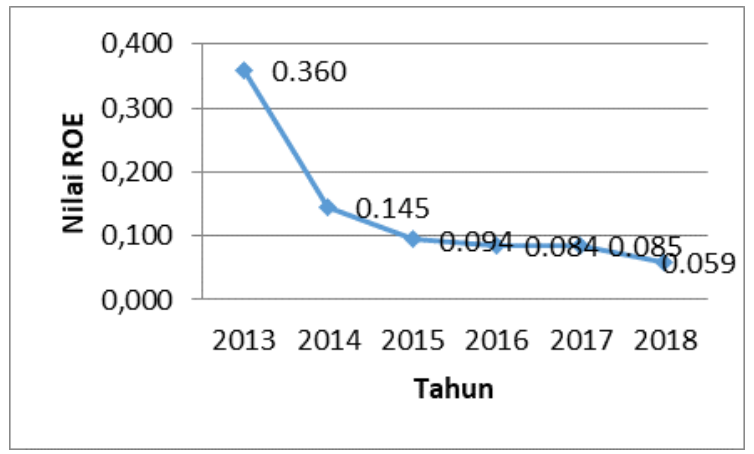

Pada grafik 1 menjelaskan tentang nilai rata-rata profitabilitas (ROE) Perusahaan Kontraktor Tahun 2013-2018 setiap tahunnya mengalami penurunan. Pada tahun 2014 terjadi penurunan nilai rata-rata Profitabilitas (ROE) terendah sebesar $-59.606 \%$ dari 0.360 menjadi 0.145 , sedangkan di tahun 2017 nilai rata-rata Profitabilitas (ROE) meningkat sebesar $0.454 \%$ dari 0.084 menjadi 0.085 . 
3) Likuditas Perusahaan Kontraktor Yang Terdaftar Di Bursa Efek Indonesia Tahun 2013-2018

Dalam penilitian ini cash ratio merupakan variable dependen. Cash ratio merupakan rasio yang menunjukan sejauh mana aktiva lancar menutupi kewajiban-kewajiban lancar.

\section{Grafik 2}

Nilai Rata-Rata Likuiditas Perusahaan Kontraktor tahun 2013-2018

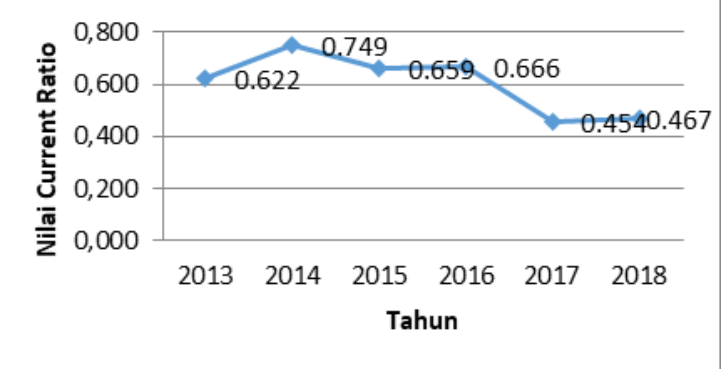

Pada grafik 2 menjelaskan tentang nilai rata-rata Likuiditas (cash ratio) Perusahaan Kontraktor Tahun 2013-2018 setiap tahunnya mengalami fluktuasi tiap tahunnya,. Pada tahun 2017 terjadi penurunan nilai rata-rata Likuiditas ( cash ratio) terendah sebesar $-31.902 \%$ dari 0.666 menjadi 0.454 , sedangkan di tahun 2014 Likuiditas (cash ratio) mengalami peningkatan nilai rata-rata tertinggi sebesar $20.506 \%$ dari 0.622 menjadi 0.749

4) Leverage (solvabilitas) Perusahaan Kontraktor Yang Terdaftar Di Bursa Efek Indonesia Tahun 2013-2018

Dalam penilitian ini, leverage keuangan (debt to assets ratio) merupakan variable dependen. Debt to assets ratio digunakan untuk menilai hutang yang dimiliki dengan kekayaan perusahaan yang dimiliki (assets). Rasio dicari dengan membandingkan seluruh hutang-hutang yang dimiliki dengan seluruh aset.

Grafik 3

Nilai Rata-Rata leverage keuangan Perusahaan Kontraktor Tahun 2013-2018

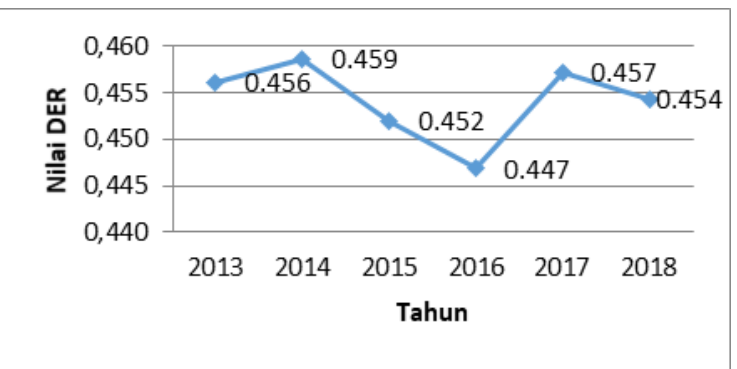

Pada grafik 3 menjelaskan tentang nilai rata-rata leverage keuangan (DAR) Perusahaan Kontraktor Tahun 2013-2018 setiap tahunnya mengalami flutkuasi tiap tahunnya,. Pada tahun 2017 terjadi peningkatan DAR teretinggi sebesar $2.316 \%$ dari 0.447 menjadi 0.457 , sedangkan di tahun 2015 nilai rata-rata DAR mengalami penurunan terendah sebesar $1.456 \%$ dari 0.459 menjadi 0.452 . 


\section{5) Ukuran Perusahaan Kontraktor Yang Terdaftar Di Bursa Efek} Indonesia Tahun 2013-2018

Dalam penelitian ini, Ukuran Perusahaan merupakan variabel independen.Ukuran perusahaan merupakanukuran aktiva yang digunakan untuk mengukur besarnya perusahaan, berapa total nilai penjualan, nilai kapitalisasi pasar, banyaknya tenaga kerja dan lain sebagainya.

\section{Grafik 4}

Nilai Rata-Rata Ukuran perusahaan Pada Perusahaan Kontraktor Tahun 2013-2018

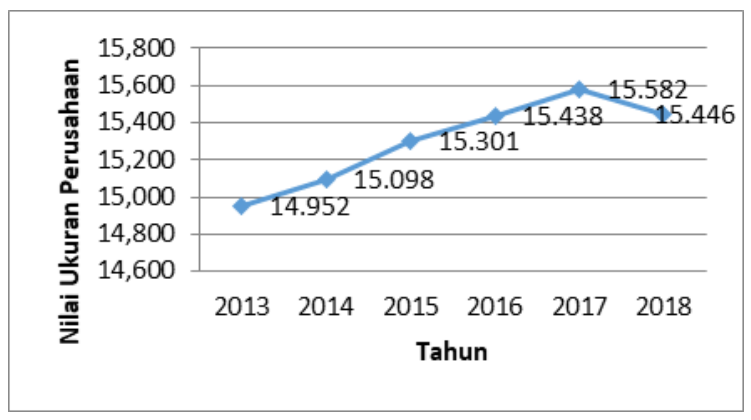

Pada grafik 4 menjelaskan tentang nilai rata-rata ukuran perusahaan pada Perusahaan Kontraktor Tahun 2013-2018 setiap tahunnya mengalami peningkatan, kecuali pada tahun 2018 mengalami penurunan. Pada tahun 2015 terjadi peningkatan nilai rata-rata ukuran perusahaan tertinggi sebesar $1.343 \%$ dari 15.098 menjadi 15.301, sedangkan di tahun 2018 nilai rata-rata ukuran perusahaan mengalami penurunan sebesar $-0.875 \%$ dari 15.582 menjadi 15.446 .

\section{b. Analisis Veripiktif}

\section{1) Kelayakan Model Chi-Square Tests}

Uji kelayakan model memberikan gambaran berupa tes terhadap kelayakan model pada Chi Square. Hal ini akan menunjukkan hasil analisis untuk mengetahui apakah distribusi data seragam atau tidak, artinya data sebaiknya berdistribusi normal yaitu munculnya keanekaragaman data dalam satu variabel yang mewakili setiap karakteristik yang dimiliki kontraktor.

\section{Tabel 1Omnibus Tests of Model Coefficients} Chi-Square Tests

\begin{tabular}{|c|c|c|c|c|}
\hline & & $\begin{array}{l}\text { Chi- } \\
\text { Square }\end{array}$ & $\mathrm{df}^{\mathrm{a}}$ & Sig. \\
\hline PRO & Pearson & & & \\
\hline BIT & $\begin{array}{l}\text { Goodness-of- } \\
\text { Fit Test }\end{array}$ & 48.342 & 193 & 1.000 \\
\hline
\end{tabular}

a. Statistics based on individual cases differ from statistics based on aggregated cases. 
Dari tabel 1 diketahui nilai probabilitas (nilai sig.) sebesar 1.00. Karena nilai prob. lebih besar dari $0.05(1.00>0.05)$ maka model diterima dan model cocok dengan data observasinya.

2) Persamaan Regresi Probit

Tabel 2 Variables in the Equation Parameter Estimates

\begin{tabular}{|c|c|c|c|c|c|c|c|}
\hline & \multirow[b]{2}{*}{ Parameter } & \multirow[b]{2}{*}{$\begin{array}{c}\text { Estima } \\
\text { te }\end{array}$} & \multirow[b]{2}{*}{$\begin{array}{l}\text { Std. } \\
\text { Error }\end{array}$} & \multirow[b]{2}{*}{$\mathrm{Z}$} & \multirow[b]{2}{*}{ Sig. } & \multicolumn{2}{|c|}{$\begin{array}{c}95 \% \\
\text { Confidence } \\
\text { Interval }\end{array}$} \\
\hline & & & & & & $\begin{array}{l}\text { Lower } \\
\text { Bound }\end{array}$ & $\begin{array}{l}\text { Upper } \\
\text { Bound }\end{array}$ \\
\hline PR & $\mathrm{X} 1$ & -.092 & .125 & -.738 & .460 & -.336 & .152 \\
\hline $\mathrm{OB}$ & $\mathrm{X} 2$ & .010 & .029 & .360 & .719 & -.046 & .066 \\
\hline $\mathrm{IT}^{\mathrm{a}}$ & $\mathrm{X} 3$ & -.023 & .180 & -.127 & .899 & -.375 & .330 \\
\hline & $\mathrm{X} 4$ & .017 & .018 & .942 & .346 & -.019 & .053 \\
\hline & Intercept & -2.916 & .267 & -10.916 & .000 & -3.183 & -2.649 \\
\hline
\end{tabular}

a. PROBIT model: PROBIT $(p)=$ Intercept + BX

Dari tabel 2 dapat diketahui bahwa persamaan Regresi Logistik Tipe Probit adalah :Ketepatan Waktu $(\mathrm{Y})=-2.916-0.092(\mathrm{X} 1)+0.010(\mathrm{X} 2)-$ $0.023(\mathrm{X} 3)+0.017(\mathrm{X} 4)$. Konstanta $(\beta 0)$ adalah -2.916 . Artinya nilai variabel dependen $(Y)=-2.916$ bila semua nilai variabel independen $(X)=0$. Bila semua variabel tidak memiliki hubungan/pengaruh (0) maka nilai ketepatan waktu sama dengan nilai konstanta. Konstanta $(\beta 1)$ adalah -0.092 . Artinya nilai variabel $\mathrm{ROE}(\mathrm{X} 1)=-0.092$ bila semua nilai variabel independen lainnya $=0$, maka Ketepatan Waktu memiliki nilai predicter sebesar -0.092. Konstanta ( $\beta 2)$ adalah 0.010. Artinya nilai variabel Cash Ratio $(X 2)=0.010$ bila semua nilai variabel independen lainnya $=0$, maka Ketepatan Waktu memiliki nilai predicter sebesar 0.010. Konstanta ( $\beta 3)$ adalah -0.023 . Artinya nilai variabel DAR $(X 3)=0.023$ bila semua nilai variabel independen lainnya $=0$, maka Ketepatan Waktu memiliki nilai predicter sebesar -0.023 . Konstanta $(\beta 4)$ adalah 0.017 . Artinya nilai variabel Ukuran Perusahaan $(\mathrm{X} 4)=0.017$ bila semua nilai variabel independen lainnya $=0$, maka Ketepatan Waktu memiliki nilai predicter sebesar 0.017

\section{3) Pengujian Hipotesis Secara Parsial}

a) Pengaruh ROE Terhadap Ketepatan Waktu

Hipotesis pertama digunakan untuk mengetahui sejauh mana pengaruh antara ROE terhadap Ketepatan Waktu. Hipotesis parsial dijelaskan kedalam bentuk statistik seperti yang tertera dibawah ini :

Ho : Variabel X tidak berpengaruh terhadap variable $\mathrm{Y}$

H1 : Variabel X berpengaruh terhadap variable $\mathrm{Y}$

\section{Keputusan}

Jika nilai sig $>0.05$, maka $\mathrm{H} 0$ diterima 
Jika nilai sig < 0.05, maka H0 ditolak

b) Pengaruh Likuiditas Terhadap Ketepatan Waktu

Hipotesis kedua digunakan untuk mengetahui sejauh mana pengaruh antara likuiditas terhadap Ketepatan Waktu. Hipotesis parsial dijelaskan kedalam bentuk statistik seperti yang tertera dibawah ini :

Ho : Variabel X tidak berpengaruh terhadap variable $\mathrm{Y}$

$\mathrm{H} 1$ : Variabel $\mathrm{X}$ berpengaruh terhadap variable $\mathrm{Y}$

\section{Keputusan}

Jika nilai sig $>0.05$, maka $\mathrm{H} 0$ diterima

Jika nilai sig < 0.05, maka H0 ditolak

c) Pengaruh Leverage Keuangan (DAR) Terhadap Ketepatan Waktu

Hipotesis ketiga digunakan untuk mengetahui sejauh mana pengaruh antara DAR terhadap Ketepatan Waktu. Hipotesis parsial dijelaskan kedalam bentuk statistik seperti yang tertera dibawah ini :

Ho : Variabel $\mathrm{X}$ tidak berpengaruh terhadap variable $\mathrm{Y}$

$\mathrm{H} 1$ : Variabel X berpengaruh terhadap variable $\mathrm{Y}$

\section{Keputusan}

Jika nilai sig $>0.05$, maka $\mathrm{H0}$ diterima

Jika nilai sig < 0.05, maka $\mathrm{H} 0$ ditolak

d) Pengaruh Ukuran Perusahaan Terhadap Ketepatan Waktu

Hipotesis keempat digunakan untuk mengetahui sejauh mana pengaruh antara Ukuran Perusahaan terhadap Ketepatan Waktu. Hipotesis parsial dijelaskan kedalam bentuk statistik seperti yang tertera dibawah ini :

Ho : Variabel X tidak berpengaruh terhadap variable $\mathrm{Y}$

$\mathrm{H} 1$ : Variabel $\mathrm{X}$ berpengaruh terhadap variable $\mathrm{Y}$

\section{Keputusan}

Jika nilai sig > 0.05, maka $\mathrm{H} 0$ diterima

Jika nilai sig $<0.05$, maka H0 ditolak

\section{Pembahasan}

\section{a. Pengaruh Profitabilitas Terhadap Ketepatan Waktu}

Berdasarkan hasil perhitungan yang telah dikemukakan oleh peneliti, maka diketahui bahwa ROE tidak berpengaruh terhadap ketepatan waktu yang dinyatakan dengan nilai sig. ROE tersebut $>0.05$.Hal ini berarti Ho diterima dan H1 ditolak, sehingga variable ROE tidak dapat pengaruh secara parsial terhadap variable Ketepatan Waktu. Hasil penelitian tidak berpengaruh dengan perusahaan mendapatkan keuntungan yang seharusnya merupakan kabar baik bagi pihak eksternal maupun perusahaan, kemungkinan menjadikan tanggungjawab pihak ketiga lainnya dalam hal ini Akuntan Publik karena dalam melakukan pengujian, akuntan publik harus benar-benar yakin atas perolehan keuntungan tersebut apakah telah disajikan secara wajar dan benar. 
Kemungkinan hal tersebut yang menjadikan lebih lama dalam penyelesaian laporan keuangan, perlu ada peneltian lanjutan dan juga disebabkan profitabilitas tidak dapat memberikan pengukuran yang memadai atas efektivitas keseluruhan perusahaan dan bukan merupakan satu- satunya tolok ukur untuk mempengaruhi ketepatan waktu laporan keuangan.

Hasil ini sejalan dengan penelitian yang dilakukan oleh Siti Hamidah \& Diana Fajarwati (2015) yang menyimpulkan bahwa Profitabilitas tidak berpengaruh terhadap penyampaian laporan keuangan, namun bertolak belakang dengan penelitian yang dilakukan oleh Susilo \& Fatmayeti (2015) yang menyimpulkan bahwa Profitabilitas berpengaruh terhadap penyampaian laporan keuangan.

\section{b. Pengaruh Likuiditas Terhadap Ketepatan Waktu}

Berdasarkan hasil perhitungan yang telah dikemukakan oleh peneliti, maka diketahui bahwa Cash Ratio tidak berpengaruh terhadap ketepatan waktu yang dinyatakan dengan nilai sig. Cash Ratio tersebut $>0.05$. Hal ini berarti Ho diterima dan $\mathrm{H} 1$ ditolak, sehingga variable Cash Ratio tidak dapat berpengaruh secara parsial terhadap variable Ketepatan Waktu.

Hasil ini sejalan dengan penelitian yang dilakukan oleh Siti Hamidah \& Diana Fajarwati (2015) yang menyimpulkan bahwa Cash Ratio tidak berpengaruh terhadap penyampaian laporan keuangan, namun sebaliknya hasil penelitian yang dilakukan oleh Nasution (2013) berbeda, karena disebabkan oleh perbedaan subjek penelitiannya yaitu meneliti hanya 83 perusahaan manufaktur dengan periode penelitian dari tahun 2009 - 2011, serta perbedaan criteria dari sampling. Hasil penelitian dari variabel ini memiliki kesamaan dengan variabel profitabilitas, yang walaupun likuiditas yang tinggi merupakan kabar baik bagi pengguna laporan keuangan, karena mengindikasikan perusahaan sanggup memenuhi kewajiban jangka pendeknya, namun likuiditas bukan merupakan fokus kabar baik bagi pengguna laporan keuangan.

\section{c. Pengaruh Leverage Terhadap Ketepatan Waktu}

Berdasarkan hasil perhitungan yang telah dikemukakan oleh peneliti, maka diketahui bahwa DAR tidak berpengaruh terhadap ketepatan waktu yang dinyatakan dengan nilai sig. DAR tersebut $>0.05$. Hal ini berarti Ho diterima dan H1 ditolak, sehingga variable DAR tidak dapat berpengaruh secara parsial terhadap variable Ketepatan Waktu. DAR tidak berpengaruh signifikan terhadap ketepatan waktu penyampaian laporan keuangan, sehingga semakin tinggi maupun rendahnya tingkat DAR tidak memiliki pengaruh yang signifikan terhadap panjang pendeknya penyampaian laporan keuangan. Hal ini disebabkan manajemen tidak menganggap DAR yang tinggi sebagai berita buruk bagi perusahaan yang mengakibatkan penundaan dalam penyampaian laporan keuangan dan masalah hutang dianggap biasa dan bukan masalah yang luar biasa bagi sebuah perusahaan selama masih ada kemungkinan penyelesaiannya, 
sehingga informasi tentang hutang kemungkinannya diabaikan oleh manajemen perusahaan.

Hasil ini sejalan dengan penelitian yang dilakukan oleh Viola Syukrina E Janrosl (2018) yang menunjukkan bahwa DAR tidak berpengaruh terhadap penyampaian laporan keuangan. Hal ini disebabkan perusahaan yang memiliki debt to equity rasio yang tinggi menunjukkan adanya kemungkinan bahwa perusahaan tersebut tidak bisa melunasi kewajiban atau hutangnya baik berupa pokok maupun bunganya. Sehingga ini merupakan berita buruk bagi perusahaan. Oleh sebab itu pihak manajemen cenderung akan menunda penyampaian laporan keuangannya, namun bertolak belakang dengan hasil penelitian yang dilakukan Ira Septriana (2010) dan Fitriani (2010) menyatakan bahwa rasio leverage mempunyai pengaruh yang positif dan signifikan dalam ketepatan waktu pelaporan keuangan.

Berdasarkan hasil perhitungan yang telah dikemukakan oleh peneliti, maka diketahui bahwa ukuran perusahaan tidak berpengaruh terhadap ketepatan waktu yang dinyatakan dengan nilai sig. Ukuran Perusahaan tersebut $>0.05$.Hal ini berarti Ho diterima dan H1 ditolak, sehingga variable Ukuran Perusahaantidak dapat berpengaruh secara parsial terhadap variable Ketepatan Waktu. Ukuran Perusahaan tidak berpengaruh signifikan terhadap ketepatan waktu penyampaian laporan keuangan, hal ini dikarenakan perusahaan dengan ukuran besar maupun kecil mempunyai kemungkinan yang sama dalam menghadapi tekanan atas penyampaian laporan keuangan.

Hasil ini sejalan dengan penelitian Khairudin, Aminah \& Anggita (2018) yang menunjukkan bahwa ukuran perusahaan tidak berpengaruh terhadap penyampaian laporan keuangan, namun bertolak belakang dengan hasil penelitian yang dilakukan Prima Noermaning Attarie (2016) dan Valeda Utari (2011) menyatakan bahwa ukuran perusahaan mempunyai pengaruh yang positif dan signifikan dalam ketepatan waktu pelaporan keuangan, karena disebabkan oleh perbedaan subjek penelitiannya yang memiliki 54 sampel perusahaan manufaktur (menggunakan aturan rumus slovin) dengan periode penelitian dari tahun 2004 - 2007, serta perbedaan criteria dari sampling. Dan dari hasil penelitian ini menunjukkan bahwa perusahaan besar belum tentu menyampaikan laporan keuangannya dengan tepat waktu, sebaliknya perusahaan kecil belum tentu menyampaikan laporan keuangannya tidak tepat waktu. Ketepatan waktu penyampaian laporan keuangan dipengaruhi oleh seberapa besar rasa tanggung jawab perusahaan dalam mematuhi peraturan yang telah ditetapkan. Selain itu, besarnya aktiva belum tentu menjadi tolak ukur utama dari ukuran perusahaan, terdapat kemungkinan komponen lain yang dapat dijadikan parameter dalam mengukur besarnya perusahaan kemungkinan seperti total penjualan, jumlah tenaga kerja, dan kapitalisasi pasar. 


\section{Kesimpulan}

Berdasarkan hasil analisis dan temuan penelitian mengenai pengaruh profitabilitas, likuiditas, leverage keuangan, dan ukuran perusahaan terhadap ketepatan waktu pelaporan keuangan pada perusahaan kontraktor yang terdaftar di Bursa Efek Indonesia 2013-2018, dapat diperoleh kesimpulan sebagai berikut hasil pengujian secara parsial tidak terdapat pengaruh profitabilitas (ROE) terhadap ketepatan waktu. Hasil pengujian secara parsial tidak terdapat pengaruh likuiditas (Cash Ratio) terhadap Ketepatan Waktu. Hasil pengujian secara parsial tidak terdapat pengaruh leverage (DAR) terhadap Ketepatan Waktu. Hasil pengujian secara parsial tidak terdapat pengaruh ukuran perusahaan terhadap Ketepatan Waktu 


\section{BIBLIOGRAFI}

Astuti, Widia, \& Erawati, Teguh. (2018). Pengaruh Profitabilitas, Umur Perusahaan dan Ukuran Perusahaan Terhadap Ketepatan Waktu Penyampaian Laporan Keuangan Perusahaan. Kajian Bisnis STIE Widya Wiwaha, 26(2), 144-157.

Indonesia, Ikatan Akuntansi. (2017). Pengertian Standar Akuntansi Keuangan (SAK). Retrieved from Ikatan Akuntansi Indonesia: http://iaiglobal. or. id/v03 ....

Riswan, Riswan, \& Saputri, Tri Lestari. (2016). Pengaruh Profitabilitas, Ukuran Perusahaan, Debt to Equity Terhadap Ketepatan Waktu Penyampaian Laporan Keuangan (Studi pada Perusahaan Asuransi yang Terdaftar di BEI). Jurnal Akuntansi Dan Keuangan, 6(1).

Siagian, Ade Onny, \& Indra, Natal. (2019). Pengetahuan Akuntansi Pelaku Usaha Mikro Kecil dan Menengah (UMKM) Terhadap Laporan Keuangan. Syntax Literate; Jurnal Ilmiah Indonesia, 4(12), 17-35.

Sugiyono. (2017). Metode Penelitian Kuantitaif, Kualitatif, Dan R\&D. Bandung: ALFABETA, cv.

Valentina, I. Gst Ayu Putu Bunga. (2018). Pengaruh Profitabilitas, Ukuran Perusahaan, Struktur Kepemilikan, Leverage, dan Umur Perusahaan Pada Ketepatan Waktu Pelaporan Keuangan. E-Jurnal Akuntansi, 22(1 Januari), 572-594. 